\title{
Análise da produção científica nacional fonoaudiológica acerca da linguagem escrita ${ }^{* * * * * *}$
}

\author{
Analysis of the speech and language national scientific production on \\ written language
}

\author{
Cíntia Mara Affornalli Munhoz* \\ Giselle Massi** \\ Ana Paula Berberian*** \\ Claudia Regina Mosca Giroto**** \\ Ana Cristina Guarinello*****
}

*Fonoaudióloga. Mestre pelo Programa em Distúrbios da Comunicação da Universidade Tuiuti do Paraná. Professora da Faculdade Palas Atena. Endereço para correspondência: Rua 7 de Setembro, 3949 - Casa 1 -

Chopinzinho - Paraná - CEP 85560-000 (cintiaaffornalli@ig.com.br).

**Fonoaudióloga. Doutora em Letras pela Universidade Federal do Paraná Professora do Mestrado em Distúrbios da Comunicação da Universidade Tuiuti do Paraná.

***Fonoaudióloga. Doutora em História pela Pontifícia Universidade Católica de São Paulo. Professora e Vice-Coordenadora do Mestrado em Distúrbios da Comunicação da Universidade Tuiuti do Paraná

****Fonoaudióloga. Doutora em Educação pela Universidade Estadual Paulista.

*****Fonoaudióloga. Doutora em Letras pela Universidade Federal do Paraná.

******Pesquisa Realizada na Universidade Tuiuti do Paraná

Artigo de Pesquisa

Artigo Submetido a Avaliação por Pares

Conflito de Interesse: não

Recebido em 12.12.2006.

Revisado em 02.03.2007; 26.03.2007; 30.07.2007.

Aceito para Publicação em 30.07.2007.

\section{Abstract}

Background: national scientific production on written language in the scope of the Speech-Language and Hearing Sciences. Aim: to analyze part of the production of the Brazilian Speech-Language and Hearing Sciences on written language, between the years of 1980 and 2004, considering the following: publication period; distribution per period; types of publication; themes; and authorship. Method: this research was developed through the selection and analysis of documents, such as; books, book chapters, and scientific articles published in seven national journals of the Speech-Language and Hearing Sciences (1980 to 2004). Results: scientific written production found in the studied period consisted of 236 publications. From this total, 3.39\% were published during the $80 \mathrm{~s} ; 44.1 \%$ during the $90 \mathrm{~s}$; and $52.5 \%$ during the period of 2000-2004. Regarding the type of publication, $18.5 \%$ of the scientific production was published as books, $39 \%$ as book chapters and $42.5 \%$ as research articles. Considering authorship, 42 authors $(76.36 \%)$ are entailed to institutions of higher education, either as professors or as students, with a higher concentration in the State of São Paulo and a lower concentration in the State of Rio de Janeiro. Overall, the analyzed written productions considered five themes: "Written language disorders" (52\%); "Written language appropriation process" (23.5\%); "Written language and deafness" (8.90\%); "Written language and neurological disorders" (8.22\%) and "Written language and school" (7.53\%). Conclusion: this research recovered part of the scientific production on written language in the field of the Speech-Language and Hearing Sciences. The increase of publications on this theme suggests an improvement of the researches in the field of the Speech-Language and Hearing Sciences and, therefore, points to the importance of studies that analyze trends in our scientific production.

Key Words: Scientific Production Indicators; Language Studies; Research.

\section{Resumo}

Tema: a produção científica nacional sobre a linguagem escrita no âmbito da Fonoaudiologia. Objetivo: analisar parte da produção fonoaudiológica brasileira acerca da linguagem escrita, entre os anos de 1980 a 2004, levando em conta o período da publicação; a distribuição de freqüência por período; os tipos de publicações; as sub-temáticas abordadas e a autoria. Método: a pesquisa de caráter documental configurou a opção metodológica selecionada para a realização desse estudo. Foram analisados livros, capítulos de livros e artigos publicados em sete periódicos nacionais de Fonoaudiologia (1980 a 2004). Resultados: as produções científicas em torno da linguagem escrita, no período considerado, perfazem um total de 236 publicações. Desse total, 3,39\% foram publicadas na década de 1980; 44,1\% na década de 1990; e $52,5 \%$ durante o período de 2000-2004. Quanto ao tipo das publicações, $18,5 \%$ foram publicadas em forma de livro, $39 \%$ de capítulo de livro e $42,5 \%$ de artigo em periódico. Quanto à autoria das publicações, 42 autores $(76,36 \%)$, são vinculados a instituições de ensino superior, como docentes ou discentes, com maior concentração no Estado de São Paulo e menor no Rio de Janeiro. As produções analisadas versaram sobre cinco sub-temáticas: "distúrbios de linguagem escrita" (52\%); "processo de apropriação da linguagem escrita" (23,5\%); "surdez e linguagem escrita" (8,90\%); "alterações neurológicas e linguagem escrita" $(8,22 \%)$ e "escola e linguagem escrita" $(7,53 \%)$. Conclusão: a pesquisa permitiu recuperar parte da memória acerca da construção de um campo de atuação e de conhecimento da área fonoaudiológica: a linguagem escrita. $\mathrm{O}$ ascendente crescimento de publicações em torno dessa temática aponta para o implemento de pesquisas nesse campo da Fonoaudiologia e, portanto, a pertinência de estudos que objetivem analisar os rumos da produção científica relativa ao mesmo.

Palavras-Chave: Indicadores de Produção Científica; Estudos de Linguagem; Pesquisa.

Referenciar este material como:

MUNHOZ, C. M. A.; MASSI, G.; BERBERIAN, A. P.; GIROTO, C. R. M.; GUARINELLO, A. C.; Analysis of the speech and language Z national scientific production on written language (original title: Análise da produção científica nacional fonoaudiológica acerca da linguagem escrita. PróFono Revista de Atualização Científica, Barueri (SP), v. 19, n. 3, p. 249-258, jul.-set. 2007. 


\section{Introduction}

This research stemmed from a certain uneasiness related to speech-language pathology intervention focused on the written language appropriation process, and the many different aspects which are part of that process, as well as from an interest on apprehending the overall production of knowledge about such aspects. The option for the analysis of the scientific production on written language was based, therefore, on the relevance that an ample view of the characteristics of part of the national production represent to the professionals who work and/or research aspects of the theme.

Such analysis, besides favoring memory recuperation in this area of knowledge, enables the visibility of the trajectory taken in a determined time frame, offering to the interested professional a view about the available practical-theoretical resources which may subsidize interventions focused on written language.

Campanatti-Ostiz e Andrade (2005a, 2005b), as well as Freire e Passos (2005), observed that this kind of study favors the implementation of knowledge production because, besides enabling the apprehension of part of the state of the art in a given field, it underlines aspects which can be improved in subsequent publications.

According to Yamamotho et al. (1999), Brazil has been monitoring its scientific production, questioning issues like production concentrationmisperception, discrepancy amongst the various areas of knowledge and the comparison of said production with international production.

Researchers like Yamamotho et al. (2002), Ferreira e Yoshida (2004), Romancini (2004), Campanatti-Ostiz e Andrade (2005a, 2005b) have assessed publications in specialized scientific journals, as such media has academic prestige, especially for the fundamental role played in disseminating, giving accessibility and visibility to the production of knowledge, as well as in the definition, application and dissemination of quality criteria, which should guide said production.

If it is an internationally accepted fact that the measuring rule of the scientific growth and rigor of an area is related to the production of published articles in indexed journals of prestigious database (Yamamotho et al., 1999; 2002), the production of books and book chapters is worthy of note, especially in areas known as the soft sciences, such as the field of Speech-Language Pathology and
Audiology, which have the oral and written languages as their object of study and intervention.

Thus, studies that undertake assessment and analysis of scientific production in the written language area, also considering books and book chapters, are relevant in as much as they offer elements for the apprehension of aspects relative to the quantitative and qualitative representation of said production.

Although we do not have systematic studies presenting a panoramic view of the scientific speech-language pathology production focused on the written language and its related problems, that area has data which reveal some characteristic aspects of the production.

To identify the methodological-theoretical presuppositions and the possible School SpeechLanguage Pathology paradigmatic transitions in the written language area, Teixeira (2005) analyzed articles published in the scientific journals "PróFono Revista de Atualização Científica e Distúrbios da Comunicação", from 1997 to 2002. This author considered the concepts of science, written language and speech-language pathology intervention present in each article. She identified, with fundament, different theoretical perspectives, separated in three moments: first, a period in which the positivism paradigm was predominant; a second moment denominated as transition period, in which there are traces of the positivism conception as well as of the humanist conception; and a third moment, in which a group of articles question the positivist streak, adopting historical, cultural and social conceptions.

Aiming to investigate the language conceptions which subsidize scientific production regarding speech-language pathology clinic focused on the written language, Borges (2003) analyzed national and international SpeechLanguage Pathology congress annals, from the 1991-2002 period. The research's qualitative results show that, of the 116 abstracts found, 81 were based on a formalist conception of language, stemming from linguistic models that view it as a system. In a smaller number, 22 abstracts are set on enunciativediscursive and socio-discursive conceptions, which prioritize the use of language. From the quantitative point of view, this study points to a yearly increase of the general scientific production about the written language clinic in papers presented at congresses. Up to the early1990s, 
there was a restricted number of works; from 1996 on, a significant tendency towards increasing the production was seen, especially of studies focusing on the use of language.

Ferreira e Russo (1994), in a work undertaken with the objective of analyzing the literary production by Brazilian speech-language pathology therapists, from 1969 to 1994, found that the theme called written language and its disorders was the fourth amongst 14 selected issues, representing $8.33 \%$ of the total.

Designing the profile of 203 doctorate thesis defended by Brazilian speech-language pathology therapists, from the first one in 1976 to year 2003, Ferreira e Russo (2004) make available data showing that the written language thematic was worked with in $5,2 \%$ of those productions. It represented an inferior number of studies when compared to hearing, voice, oral motricity and oral language themes.

According to those authors, the distribution of the themes reflects the history of SpeechLanguage Pathology as related to the initial structure of Under-Graduate Courses and Graduate Programs in the field, which generally favored, both in their curriculum and their research lines, the hearing and oral language areas.

This study has the objective of listing and characterizing part of the Brazilian SpeechLanguage Pathology national scientific production on written language, during the 1980 and 2004 period, regarding the following aspects: publication period, frequency distribution per period, types of publication, sub-themes, and authors.

\section{Methods}

The methodological option chosen for this research was document review.

\section{Material}

Data was collected from documents. Publication about scientific speech-language pathology focused on written language was analyzed. Criteria for the selection of the sources were as follows:

. as the periodicity: production published from 1980 to 2004 ;

. as the type of production: books and book chapters and the studies published in national journals specializing in the speech-language pathology area, that is, Distúrbios de Comunicação (Communication Disorders), Pró-Fono Revista de Atualização Científica, Fono Atual, Fonoaudiologia Brasil, CEFAC - Atualização Científica em Fonoaudiologia journal, Revista da Sociedade Brasileira de Fonoaudiologia and Jornal Brasileiro de Fonoaudiologia:

. as the author: productions which have at least one Brazilian speech-language pathology therapist as one of the authors.

\section{Procedures}

This research was undertaken in the Communication Disorders Post-Graduation Program of the Universidade Tuiuti do Paraná, during 2005 and 2006.

The listing and analysis of national publications written by speech-language pathology therapists about the written language were first organized from their frequency distribution, taking in consideration the publication periods, the different types of production, the subthemes, and the authorship.

Limiting the period was adopted as a criterion at the beginning of the work, in 1980, due to the officializing of the speech and hearing therapist profession, in 1981, and the insipient speechlanguage pathology therapist national scientific production about the aforementioned thematic before that period.

There were 146 publications chosen to characterize the sub-themes, meaning, those whose authors had at least two studies published and whose names showed first in the list of authors. The sub-themes presented next were defined from reading the abstracts and the introduction of the works, and they refer to: written language disorders, written language appropriation process, neurological alterations and written language, deafness and written language, and school and written language.

To chart authorship, all speech-language pathology therapists who have at least two publications about the thematic were considered, including those who stand as co-authors.

For the identification of affiliation with higher education institutions, the information provided by the authors in the articles was considered, as well as that found on their lattes/CNPq (National Council of Scientific and Technological 
Development) curriculum, according to the Ministry of Science and Technology (2005).

\section{Results}

Results shown in Table 1, related to publications type and period, show a quantitative increase in the 1980 - 2004 period. During those 25 years, said increase relates to the production of books and book chapters as well as of articles published in the Speech-Language Pathology specific journals.

Considering the total percentage of books, book chapters and published articles, Table I data show that only three books were published from 1980 to 1984 , corresponding to $7 \%$ of the total of books published during the 1980 - 2004 period. Not one production under the form of book chapter and/or journal article was seen during the years 1980 - 1984. In the next period, 1985 - 1989, one book, one book chapter and three journal articles were published, respectively $2 \%, 1 \%$ and $3 \%$ of the total number of publications. Between 1990and 1994 , the number of books published increased to 11 (25\%), of book chapters changed to 13 (14\%), and of articles became 4 (45\%). During the next period, from 1995 to 1999 , there are 12 books (27\% of the total of published books), 16 book chapters (34\% of published chapters), and 30 articles (30\% of published articles). Therefore, it is important to stress the fact that, in the time frame under discussion, the percentage of articles published in journals increased significantly in comparison to previous periods.

In the $2000-2004$ period, 17 books (39\% of the total of published books), 34 book chapters (37\% of the total of published book chapters), and 63 articles (63\% of the total of published articles) were released.

According to results presented in Table 1, obtained with the Test for Two Proportions (Triola), the significance level is $5 \%, p=0.0000(p<0,05)$ for all types of production, that is, there was a significant increase on the Brazilian speechlanguage pathology therapist scientific productions about written language in the 1980 and 1990 decades.

This same Table I shows that from the 1990 to 2000 (until 2004) decades, there was a considerable increase related to the production of articles $(\mathrm{p}=$ $0.0001)$ considering the significance level of 5\%.

Such data prove the growing tendency as to the number of books, book chapters and articles published in journals during those 25 years (Figure 1).

This review corroborates the fact that of the 236 publications, $3.39 \%$ happened in the 1980 decade, $44.07 \%$ in the 1990 decade and 52.54 from the 2000 to 2004 period. This distribution reveals a significant increase of mentioned thematic during the last years, as the 2000 to 2004 publications, corresponding to a short period of four years, surpasses the percentage of the $80 \mathrm{~s}$ and $90 \mathrm{~s}$ publications.

It is also worthy of note the fact that the publications under book format $(\mathrm{N}=44)$ and book chapters $(\mathrm{N}=92)$ correspond, respectively, to $18.64 \%$ and $38.98 \%$ of all 236 publications, totaling an expressive percentage of $57.62 \%$ of publications in books.

TABLE 1. Distribution of Brazilian Speech-Language Pathology therapist scientific production about written language in the 1980-2004 period, according with type of publication.

\begin{tabular}{c|c|c|c|c|c|c}
\hline $\begin{array}{c}\text { Production in Five Year } \\
\text { Periods }\end{array}$ & \multicolumn{2}{|c|}{ Books } & \multicolumn{2}{c|}{$\begin{array}{c}\text { Book } \\
\text { Chapters }\end{array}$} & \multicolumn{2}{c}{$\begin{array}{c}\text { Articles in } \\
\text { Journals }\end{array}$} \\
\cline { 2 - 8 } & f & $\%$ & f & $\%$ & f & $\%$ \\
\hline 1980 to 1984 & 3 & 7 & 0 & 0 & 0 & 0 \\
1985 to 1989 & 1 & 2 & 1 & 1 & 3 & 3 \\
1990 to 1994 & 11 & 25 & 13 & 14 & 4 & 4 \\
1995 to 1999 & 12 & 27 & 16 & 34 & 30 & 30 \\
2000 to 2004 & 17 & 39 & 34 & 37 & 63 & 63 \\
Total & 44 & 100 & 92 & 100 & 100 & 100 \\
\hline
\end{tabular}

FIGURE 1. Distribution of the Brazilian Speech-Language Pathology therapist scientific production.

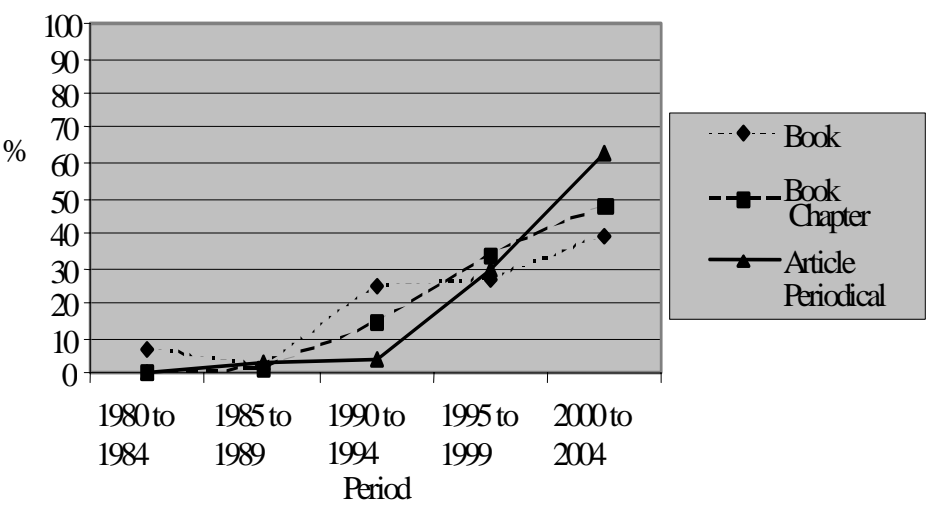


Data shown in Chart 1 refer to ties the authors have with higher education institutions, whether as teacher or as graduate and undergraduate students, strictu and latu sense.

As already described, the authors selected for analysis were those who presented at least two publications, including the ones who stand as coauthors, totaling fifty-two authors. From that group, forty-two authors $(76.36 \%)$ have ties to higher education institutions, as either teachers or students. Amongst those, thirty-five (63.33\%) are teachers in both graduate an undergraduate courses, and twenty-six (47.27\%) have ties in other institutions, totaling nineteen indications about ties. As for the student authors, there are seven (12.72\%) tied to Post-Graduation Programs.

Regarding the thirteen remaining authors (23.64\%), it was not possible to obtain information about their ties with educational institutions. In this group, two $(3.64 \%)$ had a CNPq curriculum, but did not offer references as to their ties to the institutions. As to the other eleven authors (20\%), it was not possible to establish any identification regarding working ties or $\mathrm{CNPq}$ curriculum.
Data relative to regional localization of the institutions the authors were connected to are presented in Figure 2. It is possible to observe a higher number of ties to institutions located in the Southeastern Region, with concentration in the State of São Paulo (67\%) and a lesser amount in Rio de Janeiro (7\%). The Southern Region is also well represented, as the remaining authors work in Paraná (14\%) and Rio Grande do Sul (12\%) institutions.

Table 2 shows 5 sub-themes selected from the publications analyzed.

Written language disorders characterized the sub-theme most frequently written about in the productions with higher number of publications (52\%). It corresponded to $67 \%, 42 \%$ and $55 \%$ of all themes, respectively, in books, book chapters and published journal articles. According to Table 2 data, obtained from the Test for Two Proportions, the productions that discussed written language disorders are significantly superior to the other ones in a 5\% significance level, as $\mathrm{p}=0,0000$. The remaining sub-themes did not show any significant difference.

CHART 1. Distribution of authors ties with higher education institutions.

\begin{tabular}{|c|c|c|c|c|c|c|}
\hline & & Higher Education Institution & & Authors Ties & & \\
\hline UF & $\mathrm{PB} / \mathrm{P}$ & & Teacher/One Tie & Teacher/More than one Tie & Student & TOTAL \\
\hline & & FCMC & - & 3 & - & 3 \\
\hline & & UNESP - Marília/SP & 2 & 1 & - & 3 \\
\hline & IPR & UNIFESP & 1 & - & - & 1 \\
\hline & & UNICAMP & - & 2 & 1 & 3 \\
\hline & & USP-São Paulo & 1 & - & 1 & 2 \\
\hline & & CEFAC & 1 & 1 & 1 & 3 \\
\hline & & Centro Universitário São Camilo & 1 & - & - & 1 \\
\hline SP & & MACKENZIE & - & - & 2 & 2 \\
\hline & & PUC-Campinas & 1 & - & - & 1 \\
\hline & IP & PUC- São Paulo & 8 & - & - & 8 \\
\hline & 10 & UMESP- São Bernardo do Campo & - & 1 & - & 1 \\
\hline & & UNAERP- Ribeirão Preto & 1 & - & - & 1 \\
\hline & & UNIFMU & - & 1 & - & 1 \\
\hline & & UNIMEP & 1 & 2 & - & 3 \\
\hline & & UNIP & - & 1 & - & 1 \\
\hline & IPR & UFRJ & 1 & - & - & 1 \\
\hline RJ & IP & CMSB & - & 1 & - & 1 \\
\hline & IP & UNESA & 1 & 1 & - & 2 \\
\hline & & CEFAC & - & 1 & - & 1 \\
\hline PR & IP & UNOPAR & - & 1 & - & 1 \\
\hline & & UTP & 4 & - & 1 & 5 \\
\hline & IPR & UFRG & 1 & - & 1 & 2 \\
\hline & & CESC & - & 1 & - & 1 \\
\hline RS & IP & Faculdade Nossa Senhora de Fátima & - & 1 & - & 1 \\
\hline & & IPA & 1 & 1 & - & 2 \\
\hline & & ULBRA & 1 & - & - & 1 \\
\hline TOT & & & 26 & 19 & 7 & 52 \\
\hline
\end{tabular}

Data collected in May 2006 - Legend: IP (Public Institution) and IPR (Private Institution) 
The occurrences related to the written language process appropriation came in second place, corresponding to a $23.5 \%$ of the total production: $24 \%$ of the themes discussed in books, $23 \%$ in book chapters, and $23 \%$ in published journal articles.

Third place was occupied by the sub-theme deafness and written language $(8.22 \%)$. The last place, corresponding to $7.53 \%$ of the total of the publications, was the sub-category school and written language. These comparative data are illustrated in Figure 3.

\section{Discussion}

According to data shown in Table 1, production from 2000 to 2004 surpassed the production from the 80 s and the $90 \mathrm{~s}$. Such data showed that the scientific production about written language increase followed the growth of the field as a whole, according to findings by Teixeira (1993), Ferreira e Russo (1994), Alves (2002) and Borges (2003), who identified a significantly higher number of speechlanguage pathology national scientific productions at the beginning of the $90 \mathrm{~s}$.

Those authors see this increase as a result of the following aspects: the recognition of the profession and the expansion of the number of undergraduate courses in Speech-Language Pathology at the beginning of the 80 s , the growing number of professionals with a degree in the field; the growing demand for teachers to work at the new teaching institutions; the investment those institutions made on qualifying their teachers; the rules set by the Qualification of Higher Education Personnel Coordination (Coordenação de Aperfeiçoamento do Pessoal de Nível Superior Capes), which requires as an evaluation criterion for the strict sensu Graduate Programs (PGs) the quality, quantity and regularity of teachers' intellectual production; and the growing number of speech-language pathology therapists in master's and doctorate's programs.

Amongst those aspects, Teixeira (1993), Ferreira e Russo (1994) and Alves (2002) consider important the creation and consolidation of the PGs, as master's dissertations and doctorate's thesis are the roots, and, therefore, stimulate the elaboration of articles, books and book chapters.

The correlation between research, publication and graduate work may be seen when comparing the production growth from 1990 to 2004 , with the expansion of the PGs recommended by Capes. Until 1990, there were only 2 programs in
FIGURE 2. Percentage of authors linked to teaching institutions, by region.

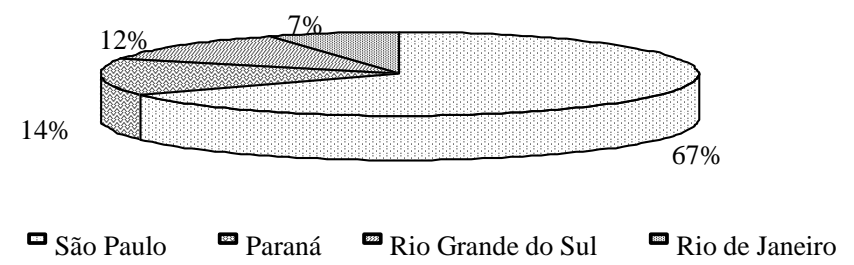

TABLE 2. Distribution of sub-themes according to publication type - 1980 to 2004.

\begin{tabular}{|c|c|c|c|c|c|c|c|}
\hline \multirow{2}{*}{$\begin{array}{l}\text { Themes Related to the } \\
\text { Written Language }\end{array}$} & \multicolumn{2}{|c|}{ Books } & \multicolumn{2}{|c|}{$\begin{array}{l}\text { Book } \\
\text { Chapters }\end{array}$} & \multicolumn{2}{|c|}{$\begin{array}{l}\text { Articles in } \\
\text { Journals }\end{array}$} & \multirow{2}{*}{$\begin{array}{l}\text { TOTAL } \\
\%\end{array}$} \\
\hline & $\mathrm{f}$ & $\%$ & $\mathrm{~F}$ & $\%$ & $\mathrm{f}$ & $\%$ & \\
\hline Written language disorder & 22 & 67 & 25 & 42 & 29 & 55 & 52 \\
\hline $\begin{array}{l}\text { Written language } \\
\text { appropriation process }\end{array}$ & 8 & 24 & 14 & 23 & 12 & 23 & 23,5 \\
\hline $\begin{array}{l}\text { Deafness and written } \\
\text { language }\end{array}$ & 0 & 0 & 8 & 13 & 5 & 9 & 8,9 \\
\hline $\begin{array}{l}\text { Neurological alterations and } \\
\text { written language }\end{array}$ & 2 & 6 & 4 & 7 & 6 & 11 & 8,2 \\
\hline School and written language & 1 & 3 & 9 & 15 & 1 & 2 & 7,5 \\
\hline Total & 33 & 100 & 60 & 100 & 53 & 100 & 100 \\
\hline
\end{tabular}

FIGURE 3. Thematic distribution of speech-language pathology scientific production according with publication type - 1989 to 2004
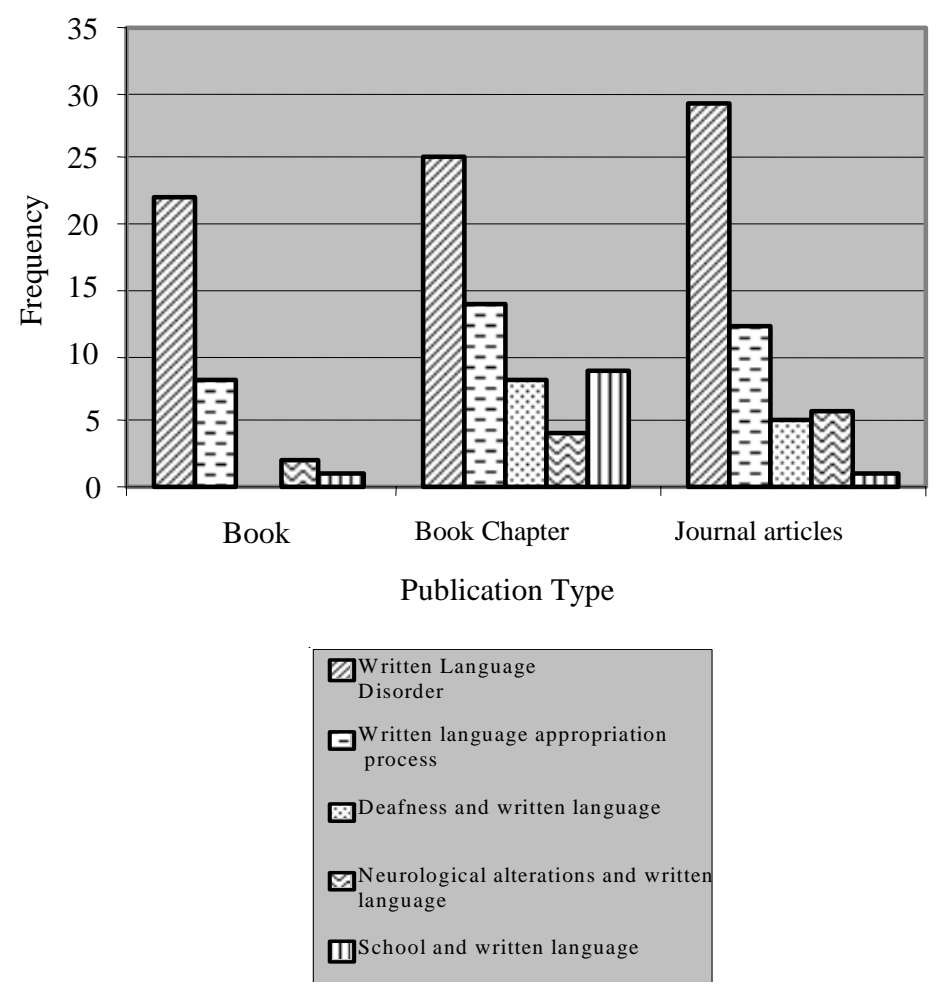
the field: the Speech-Language Pathology Program offered by PUCSP, and the Human Communication Disorders Program offered by the Paulista Medical School - São Paulo Federal University (Unifesp). From the 90s on, the professionals of the area were able to choose from 8 PGs recommended by Capes: Human Communication Disorders - Santa Maria (RS), 1994; Communication Disorders - Universidade Tuiuti do Paraná (UTP), 1998; Rehabilitation Sciences, HRAC-USP, Bauru (SP), 2001; SpeechLanguage Pathology - Veiga de Almeida University (UVARJ), 2003; Rehabilitation Sciences USP/SP, and Speech-Language Pathology at USP-FOB, Bauru (SP), 2004.

Another factor conditioned the growth in speech-language pathology production from the 1980s until the end of the 1990s: the increased number of Brazilian periodicals specialized in Speech-Language Pathology: Communication Disorders (1986), by the Pontifical Catholic University of São Paulo; Pró-Fono Scientific Updating Journal (1989), by publishing house PróFono; Up-to-date Fono (1997), by Pancast Editora; The Brazilian Speech-Language Pathology Society Journal, (1997); Brazil Speech-Language Pathology (1998), by the Speech-Language Pathology Federal Council; CEFAC Journal, by the Clinical SpeechLanguage Pathology Specializing Center; and the Brazilian Journal of Speech-Language Pathology (1999), by Bio Editora.

Amongst the science communication and implementation channels, the scientific periodicals hold an outstanding place, as they enable the exchange and dissemination of scientific works from the field, an incentive for new researches. Characteristics such as the speed of production and dissemination, geographical amplitude, capacity of agglutinating those interested on a theme, and knowledge validation give scientific journals a decisive role in the constitution and consolidation of research lines.

As Campanatti-Ostiz and Andrade (2005a, p. 153) say, "The publication of articles in indexed scientific journals favors the speed, accessibility, and visibility of the production of knowledge".

If there is no questioning the importance of journals publications for the development of the field, the productions published in books and book chapters about the written language overcame those published under the journal article form, according to data presented in Table 1 . They confirm the relevance this type of production has in the spreading of knowledge about such thematic in the Speech-Language Pathology area.
Data shown in Charter 1 confirm analysis undertaken by Teixeira (1993), Ferreira and Russo (1994), Alves (2002), Campanatti-Ostiz and Andrade (2005a) when they affirm that the production of knowledge is connected, mainly, to researchers working in teaching institutions, especially in the PGs. The prevalence of ties between authors and the institutions located in the Southeastern and Southern Regions is related to the higher number of Higher Education Institutions in those regions, as well as to the existing Graduate Programs in our country.

The results in Table 2 show evidences that the analyzed productions about written language discussed, mainly, five thematics:

\section{Written language disorders.}

2. Written language appropriation process.

3. Deafness and written language.

4. Neurological alterations and written language.

5. School and written language.

It was possible to verify, through the analysis of the productions which discussed written language disorders, that the focus on those disorders' etiological and symptomatological factors, as well as on the solutions applicable to clinical practice, was prevalent. In that material, the authors pointed mainly to individual causes, all centered on the child, as determinant for the occurrence of the disorders. Cognitive difficulties; those relative to the structural and developmental maturing of the central nervous system; the ones related to visual, space and hearing perception; and those connected to grapho-phonological correspondence were the most cited causes of the disorders. Developing phonological competencies and the stimulation of the central auditory processing were the most indicated strategies for the treatment of the disorders.

Therefore, it was possible to notice that the productions that focused on written language disorders are based on theoretical-methodological presuppositions linked to organicist and cognitive models, whether to explain the conception of the written language or to justify the intervention forms proposed for written facts classified as disorder symptoms by such models. The social, economic, political and educational aspects related to writing were not object of analysis in those productions.

The written language appropriation process is the second most discussed sub-theme. The productions that dealt with this aspect attributed great emphasis to the interaction of the child with 
other subjects and with the contexts in which those relations develop. Under the influence of theoretical models that analyze the socio-historical, politicalideological, economic and educational determinants involved in the appropriation of the written language, the productions listed in this sub-thematic criticize the organicist and mechanicist notions which give basis to teaching and clinical practices directed towards the learning/acquisition of reading and writing. The basic conception of language in those productions is considered a dialogical activity, interpersonal and determined by the socio-historical contexts. The notions of disorder and symptom are questioned when fundamented exclusively on outof-the-norm written manifestations, seeing as they are analyzed as singular marks of the writing appropriation process. Finally, those manifestations are analyzed as disclosures of the linguistic processes and the perception of the world specially created by the individuals from the material and subjective conditions available in the social group they belong to.

As far as the productions related to deafness and written language are concerned, the analysis focus on the deaf child's inclusion in the regular school system, and her access to the written language, as well as the speech-language pathology intervention related to written language and deafness. It is a recurrent criticism in those publications the lack of technical and human resources in the Brazilian educational system, as this deficiency restricts and/or makes this language mode inaccessible to deaf people. It is also object of analysis the procedures and criteria used in the investigation about deaf people's writing, considering its relations with the oral text, the Brazilian Signal Language (Libras), and the linguistic variations. Predominant in those productions is the socio-historical conception, in which writing is understood as the individual's social and constitutive practice.

The sub-theme neurological alterations and written language included the publications which discussed the relation between written language and aphasia, with alexia/pure dyslexia, and with the degenerative diseases of the central nervous system. The heterogeneity as to the adoption of theoreticalmethodological presuppositions that fundament those productions was demonstrated, as some authors based themselves on models that prioritized organic conditions and others on a discursive perspective, which focus the subjective conditions involved in the functioning of the language.
Lastly, the sub-theme school and written language, the least discussed one in the productions, was seen under two perspectives. The first one was directed to the presentation of models of speech-language pathology intervention in school focused on individual actions, centered on the children and on auditory, visual and motor abilities. Representing $45 \%$ of this type of production, the analysis is mainly directed to triage proposals and teachers and family guidance. The other perspective, adopted in $55 \%$ of the productions, refers to the analysis of theoreticalpractical fundaments directed towards collective actions in the school context, which promote the access to the written language by the children. These publications emphasize the importance of a partnership between speech-language pathology therapists and educators, noting that it is the therapists' obligation to socialize the knowledge about the different dimensions participating in the written language appropriation processes.

Considering the historical links between SpeechLanguage Pathology and Education, as well as the fact that the written language formal appropriation processes happen mostly in school (Berberian, 2001; Siqueira e Monteiro, 2006), the incidence of productions related to this sub-thematic may be considered restricted, when compared to the others. This data reveals that aspects involving the written language are still predominantly investigated in the speech-language pathology clinic sphere. One may conclude that the educational system and institutions are not yet considered privileged spaces for the development of speech-language pathology researches focused on the written language.

\section{Conclusion}

Starting with some questioning related to speechlanguage pathology intervention focused on the written language appropriation processes, and having an interest in visualizing a panorama of the national production by speech-language pathology therapists on this thematic, it was possible to view through this work the significant increase in the number of publications about written language in the 1980-2004 period. The publications trajectory in the delimited time frame enables us to realize that, of a total of 236 productions, more than half, that is 124 publications, were concentrated between 2000 and 2004.

The collected data demonstrate that the increased number of scientific productions about the written language followed the growth of production in the area as a whole. This growth was conditioned to the 
consolidation and expansion, beginning in the 90s, of Brazilian periodicals specific of the SpeechLanguage Pathology area and undergraduate and graduate courses related to it. Those facts made possible not only the increase in publication but also a larger amount of exchange and propagation of scientific knowledge amongst the speech-language pathology researchers in our country.

Concerning the type of the analyzed productions, publications under the form of books and book chapters are more recurrent, even though the publications under the form of articles increased from the 1990 decade. This fact points towards the importance of such publications, as well as to the necessity of systematizing criteria for their evaluation and validation.

The production analysis showed that most of the authors responsible for the publications are linked to Higher Studies Institutions, especially those which have Graduate Programs in the area, mainly located in the Southern and Southeastern Regions.

This research offers elements for some strategic decisions regarding the themes discussed in the publications, especially related to research direction, as it pointed to aspects which, not being prioritized in the scientific production, may limit the field to attend demands related to certain problematics.

Concluding, this work created the opportunity for recovering part of the memory about the construction of an area of the speech-language pathology activity and knowledge: the written language. The primary intention was to contribute with an overall view of the national production distribution and characteristics related to that field. Collected data affirm the validity of developing researches which enable the analysis of SpeechLanguage Pathology scientific production. The diversified sub-areas spectrum, objects of studies, methods, and contexts from which works and publications are developed suggest new studies stemming from the delimitation of the SpeechLanguage Pathology specific areas. 


\section{References}

ALVES, M. R. M. A produção fonoaudiológica nacional em motricidade oral: 1970 a 2000. 2002. $101 \mathrm{f}$. Dissertação (Mestrado em Distúrbios da Comunicação) Faculdade de Ciências Biológicas e da Saúde, Universidade Tuiuti do Paraná, Curitiba.

BERBERIAN, A. P. Linguagem e fonoaudiologia: uma análise histórica. R. Dist. Comun., São Paulo, v. 12, n. 2, p. 265-278, jun. 2001.

BORGES, L. B. N. A escrita que a fonoaudiologia vem escrevendo. 2003. 146 f. Dissertação (Mestrado em Fonoaudiologia) - Departamento de Fonoaudiologia, Pontifícia Universidade Católica, São Paulo.

CAMPANATTI-OSTIZ, H.; ANDRADE, C. R. F. Periódicos nacionais em fonoaudiologia: caracterização estrutural. R. Soc. Bras. Fonoaudiol., São Paulo, v. 10, n. 3, p. 147-154, jun.-set. 2005a.

CAMPANATTI-OSTIZ, H.; ANDRADE, C. R. F. Periódicos nacionais em fonoaudiologia: caracterização de termos. R. Fonoaudiol. Bras., Brasília, v. 3, n. 1, p. 14 , jun.-set. 2005b.

MINISTÉRIO DA CIÊNCIA E TECNOLOGIA. CNPQ: conselho nacional de desenvolvimento científico e tecnológico, 2005. Disponível em: 〈www.cnpq.br〉. Acesso em: 27 dez. 2005.

FERREIRA, L. P.; RUSSO, I. C. P. A produção literária do fonoaudiólogo brasileiro. Pró-Fono. Carapicuíba, 1994.

FERREIRA, L. P.; RUSSO, I. C. P. Fonoaudiólogos doutores no Brasil: segundo áreas de atuação e programas. Pró-Fono R. Atual. Cient., Baurueri (SP), v. 16, n. 1, p. 119-130, jan.-abr. 2004.

FERREIRA, N. S; YOSHIDA, E. M. P. Produção Científica sobre psicoterapias breves no Brasil e demais países latinoamericanos (1990-2000). Est. Psicol., Natal, v. 3, n. 3, p. 523-531, set.-dez. 2004.
FREIRE, R. M.; PASSOS, M. C. Uma análise da produção de conhecimentos no interior do PEPG em fonoaudiologia: de sua fundação até o milênio. R. Dist. Comun., São Paulo, v. 17, n. 1, p. 37-43, abr. 2005.

ROMANCINI, R. Periódicos brasileiros em comunicação: histórico e análise preliminar. São Leopoldo, RS, v. 2, n. 39, p. 1-18, fev. 2004.

SIQUEIRA, C. L. O.; MONTEIRO, M. I. B. A relação entre a fonoaudiologia e a escola: reconstruindo possibilidades. R. Dist. Comun., São Paulo, v. 18, n. 2, p. 259-268, ago. 2006.

TEIXEIRA, A. C. B. Leitura e escrita em fonoaudiologia: a transição de paradigmas. 2005. 118 f. Dissertação (Mestrado em Educação) - Faculdade de Filosofia e Ciências, Universidade Estadual Paulista, Marília.

TEIXEIRA, D. O. A trajetória da pesquisa acadêmica em distúrbios da comunicação: tendências temáticas 1978-1992. 1993. 77 f. Dissertação (Mestrado em Distúrbios da Comunicação) - Departamento de Fonoaudiologia, Pontifícia Universidade Católica, São Paulo.

TRIOLA, M. F. Introdução à estatística. Rio de Janeiro: LTC - Livros técnicos e científicos, 1999.

YAMAMOTO, O. H.; MENADRO, P. R. M.; KOLLER, S. H.; LOBIANCO, A. C.; HUTZ, C. S.: BUENO, J. L.; GUEDES, M. C. Avaliação de periódicos científicos brasileiros da área da psicologia. Ci. Inf., Brasília, v. 31, n. 2, p. 163-177, maio-ago. 2002.

YAMAMOTO, O. H.; SOUZA, C. C.; YAMAMOTO, M. E. A produção científica na psicologia: uma análise dos periódicos brasileiros no período de 1990-1997. Psicol.: Refl. Crít., Porto Alegre, v. 12, n. 2, p. 549-565, maioago. 1999. 